\title{
Production and Characterization of Palm Oil Based Epoxy Biocomposite by Response Surface Methodology Design
}

\author{
Hakan Sahal ${ }^{1}$ (D) Ercan Aydogmus ${ }^{2}$ (D) \\ ${ }^{1}$ Munzur University, Department of Food Processing, Tunceli, Turkey \\ ${ }^{2}$ Firat University, Department of Chemical Engineering, Elazig, Turkey
}

\begin{abstract}
Tn this research, some physical and chemical properties of the biocomposite obtained from synthesized epoxy modified palm oil (MPO) and epoxy resin have been characterized. The experimental study plan is made according to Response Surface Methodology (RSM) and biocomposites with different MPO rates are obtained. The chemical bond structure of MPO and epoxy biocomposite has been evaluated with Fourier Transform Infrared Spektrofotometre (FTIR). The experimental and RSM model results obtained, the density of the biocomposite rise as the MPO rate increases. It is determined that the Shore $\mathrm{D}$ hardness of the biocomposite is inversely proportional to the MPO rate by mass. As the MPO ratio (wt.\%) increases in the biocomposite, the thermal conductivity coefficient and thermal stability also raise. In the thermal decomposition experiments of the obtained biocomposite, it is observed that the thermal stability of the composite goes up as the MPO rate rises. Activation energies are calculated using the Flynn Wall Ozawa, Kissinger, and Coats Redfern models. The activation energies calculated for the 9th, 2nd, and 13th experiments according to the Flynn Wall Ozawa method are approximately 139.65, 143.56, and $145.28 \mathrm{~kJ} / \mathrm{mol}$, respectively. The function $\left(f=(1-\alpha)^{1.273}\right)$ with the highest $R^{2}$ value has been determined according to the Coats Redfern method, and the deviation in Flynn Wall Ozawa and Kissinger model results was below $7 \%$.
\end{abstract}

Keywords:

Biocomposite; Modified palm oil; Sulfonamide; Characterization; Thermal decomposition.
Article History:

Received: 2021/06/24

Accepted: 2021/11/30

Online: 2021/12/31

Correspondence to: Hakan Sahal,

Munzur University, Food

Processing, Tunceli, TURKEY

E-Mail: hakansahal@munzur.edu.tr

\section{INTRODUCTION}

Today, social awareness of the environmental im1 pacts of plastics is increasing, and therefore environmentally friendly materials are sought for the plastics industry [1-4]. For this reason, in addition to being environmentally friendly, the tendency towards natural fibers is increasing due to their low cost, easy processing, low density, good corrosion resistance, and high strength in wide industrial applications [5-8, 9-14]. Moreover, natural fibers become an alternative to glass fibers by being applied to reinforced polymer composites and natural-based resins, as they contain hydrogen bonds and other bonds that reinforce the structure $[15,16]$. The use of bio-fibers as substitutes for synthetic fibers (carbon, and glass) as fillers in the development of polymer matrix composites has attracted much attention [17].

There is increased awareness about the properties of natural fiber-based epoxy composites to meet engi- neering requirements [18]. The use of epoxy composite materials reinforced with natural fibers is increasing strongly in many industrial areas, especially in the automotive sector [19-23], in civil construction [20], and marine production [21] due to their low cost of processing. German carmakers, soon followed by other manufacturers, took the lead in introducing natural fiber composites for interior and exterior applications; parcel shelves, door panels, mirror casing, backrests, voltage stabilizer cover, seat cushions, dashboard parts, projector cover helmet, roof linings, etc. In the civil construction area, they can be used for; beams, building panels, roofing products, autoclaved cement composite, and water tanks. For shipbuilding, the adoption of green composites can potentially represent a valid substitute for fiberglass. These include both purposely grown and harvested fibers, as well as those recovered from agricultural waste. Thanks to their recyclability and renewability, biocomposites allow them to comply with more and more 
stringent environmental protection regulations $[24,25] \mathrm{imp}-$ roving also the cost-effectiveness [26]. Increasing the mechanical performance of these materials is a mandatory task to spread their use not only in non-structural applications but also in semi and proper structural applications limited by their failure mechanisms [27].

Vijaya Ramnath et al. [28] conducted a study on the evaluation of mechanical properties of abaca-jute-glass fiber reinforced epoxy composite and revealed that abaca fiber had the highest flexural strength compared to jute fiber, with the values of 12.5 and $11.9 \mathrm{MPa}$, respectively, since its strength increased with improved interfacial adhesion. Besides that, Abaca exhibited more strength when it absorbed moisture.

Szolnoki et al. [29] reinforced twill woven hemp fabric with epoxy composites and discovered that the modification of the fabrics led to decreased flammability of the reference matrix composites, characterized with increased limiting oxygen index values and reduced heat release rate by $25 \%$. Moreover, composites of modified fabric showed improvements in static and dynamic mechanical properties.

Pickering et al. [30] experimented on aligned short harakeke fiber (New Zealand flax) mats impregnated with epoxy resin. The result showed that these composites were found to possess significantly higher tensile properties at $46 \%$ fiber loading, than planar random-oriented short fiber composites, with the values of $136 \mathrm{MPa}$ and 76.2 MPa, respectively. The epoxy resin is a feasible polymer, which has effective strength, good toughness, and appreciable resilience. It has good resistance to moisture and chemical attack. It also has great electrical insulating properties and is devoid of volatile matter [31].

Abu Bakar et al. [32], through their study, reported that one of the flaws of natural fibers is poor compatibility with its matrix. Moreover, studies done by Hassan et al. [33] showed that the recyclability of natural fiber within the automotive component had reduced the automotive weight. The use of biocomposite helped in a $25 \%$ reduction of vehicle weight, which consequently contributed to saving 39.45 trillion of crude oil [33]. Besides that, this material can be used for the composite frame in electromobility vehicles, as it will reduce energy consumption [9]. Currently, natural fibers are used as fillers to replace glass fiber in polymer composites [34].

The incompatibility and poor adhesion of natural fiber in a polymer matrix are usually addressed by fiber treatment and modification to enhance effective wetting and uniform dispersion. The primary techniques used for fiber treatment and modification can be grouped into fiber pretreat- ment, surface coating modified with coupling agents, and in situ compatibilization during processing depending on the practical applications. Mercerization, a chemical treatment using alkali, is widely used to fibrillate and purify fibers (partially removing oil, wax, pectin, hemicellulose, and lignin) before composite fabrication.

For example, Rihayat et al. [35] and Wang et al. [36] have reported that biocomposites treated with alkaline solutions and silane fusing agents have twice the tensile strength of composites without temporary treatment. Mahmoud et al. [37], Kang and Kim [38] reported an increase in tensile strength, modulus of elasticity, and moisture resistance of biocomposites with the coupling agent in the composite matrix. Alkalisation refers to the treatment of fibers in an alkaline solution by dissolving some unstable fiber components such as hemicellulose, lignin, pectin, and other impurities so that the surface of the fiber becomes cleaner and rougher, which results in better mechanical interlocking between the fiber and the polymer. Lee and Wang [39], and Fan [40] have found that bamboo fibers treated at $6 \% \mathrm{NaOH}$ produce the highest tensile properties of single fibers and matrix adhesion strength. Similar studies on other natural fibers using $5 \% \mathrm{NaOH}$ concentration revealed comparable results, with higher $\mathrm{NaOH}$ concentrations causing a decrease in mechanical properties.

In many studies in the literature, vegetable oils have been modified and used in the synthesis of composites. Especially, biocomposite production can be made as a result of the epoxidation of triglyceride structures found in vegetable oils [41]. For example, when palm oil is modified by various processes, a biopolymer can be easily obtained by a chemical reaction [42]. It is known that the synthesized biocomposite, in which palm oil is used in the production of polyester composites, improves some of the thermophysical properties [43]. Evaluation of such similar sources in the production of biocomposites with epoxy resin is becoming more and more common. Because the epoxidation of triglyceride structures in vegetable oils easily offers many options for the development of bio-epoxy composites as raw materials. The advantages of the synthesized bio-epoxy composites such as being environmentally friendly, more thermally stable, and easy to process make such studies important [44].

The original aspect of this research is the synthesis of biocomposite using the modified epoxy palm oil. Unlike studies in the literature, palm oil has been modified that functional epoxy and hydroxyl structures are bonded for the production of biocomposite.

This study aims to treatment fiber with alkali where had effects on the mechanical properties improvement of natural fiber such as increased cellulose content and the 
degree of crystallinity, which is indicative of higher fiber strength and stiffness; increased surface roughness topography for better mechanical interlocking between the fiber and matrix; increased cellulose exposure for increased bonding/reaction sites on the fiber surface; and increased surface energy for better wetting and compatibility. Treatment with a mild alkaline condition is typically sufficient to remove fiber impurities with minimal impact on the fiber texture and structure whereas higher alkaline concentration can lead to excessive removal of lignin and fiber damage. Furthermore, according to the study, the use of cellulosic fiber as reinforcement can reduce the material cost and at the same time raising strength to weight ratios [28].

\section{MATERIALS AND METHODS}

\section{Materials}

All chemicals used for the biocomposite production and analysis have been supplied from Merck and used without purifications. Epoxy raw material and hardener components are procured from Polisan (Turkey). Experimental studies use ethyl acetate (99.5\%), ortho-phosphoric acid (85\%), ethanol (99.5\%), hydrochloric acid (37\%), methanol (99.5\%), and hydrogen peroxide (35\%). Palm oil with a density of $904 \mathrm{~kg} / \mathrm{m}^{3}$ and a viscosity of $77 \mathrm{cP}$ is supplied from commercial companies.

\section{Methods Used in The Experimental Study}

In the experimental study, firstly palm oil $(100 \mathrm{~g})$ is mixed with acetic acid (45 g), ethyl acetate (10 g), and hydrogen peroxide $(90 \mathrm{~g})$. Phosphoric acid $(0.02 \mathrm{~g})$ is added to the mixture and stirred at $500 \mathrm{rpm}$ and $60^{\circ} \mathrm{C}$ for 6 hours. After this process is completed, the light phase is recovered using a vacuum rotary evaporator. Then methanol (70 $\mathrm{ml})$, ethanol $(30 \mathrm{ml})$, and distilled water $(100 \mathrm{ml})$ are added to the system. $\mathrm{HCl}(0.02 \mathrm{~g})$ is dropped into the mixture and the aqueous and organic phases are separated after being mixed at $500 \mathrm{rpm}$ and $70^{\circ} \mathrm{C}$ for 12 hours. The oil phase is washed with warm water until the $\mathrm{pH}$ is neutral. The modified epoxy palm-oil-based raw material (MPO) is obtained by removing impurities (methanol, ethanol, and water) with a vacuum rotary evaporator.

In the second stage, $5 \mathrm{~g}$ of MPO and $0.5 \mathrm{~g}$ of 4-(2-aminoethyl)benzene sulfonamide were placed in a flask. It was reacted in reflux state for 2 hours by adding $10 \mathrm{~mL}$ of ethanol. Then, the reaction temperature was brought to $60^{\circ} \mathrm{C}$ and the reaction was continued for 72 hours. At the end of the period, the second stage was passed. MPO was added to commercial epoxy medium according to the ratios indicated in 0-10 wt.\% and mixed at $500 \mathrm{rpm}$ for 15 minutes

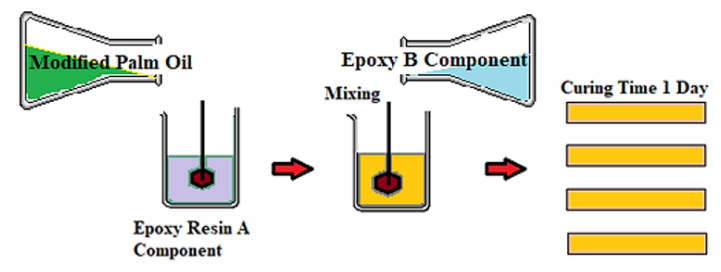

Figure 1. Experimental working schema for the biocomposite production.

to ensure the homogenization of the composite. Then, the hardener part was added to the medium and mixed at the same mixing speed for 15 minutes. At the end of the period, the solvent was removed with the evaporator and quickly transferred to the standard molds. It was left to cure for 24 hours at room conditions. Commercial epoxy resin has approximately $5 / 8$ main components and 3/8 hardener components by mass. Biocomposite production was carried out according to the order in the schema in Fig. 1.

The chemical bond structure of the bio-epoxy composite has been analyzed with an FTIR spectrophotometer. The FTIR spectrum of each sample has been determined as transmittance (\%) in the wavelength range of $600 \mathrm{~cm}^{-1}$ to $4000 \mathrm{~cm}^{-1}$. FTIR measurements have been made using Sh1madzu QATR-S (IR Spirit S1102SC). The FTIR spectrum of biocomposites has been investigated by ATR method directly in solid powder form without making potassium bromide $(\mathrm{KBr})$ pellets. Besides, the thermal decomposition of the biocomposite with the proportional integral derivative (PID) system, its hardness with the Shore D test, and its thermal conductivity coefficient (Thermtest TLS-100) with the thermal conductivity measuring device have been determined.

Thermal decomposition kinetics of biocomposites in an inert environment (nitrogen) have been investigated with the PID-controlled system. In this system, the temperature increase of $10 \mathrm{~K} / \mathrm{min}$ from $25^{\circ} \mathrm{C}$ to $605^{\circ} \mathrm{C}$ is studied in nonisothermal conditions. The PID system has a total diameter of $19.5 \mathrm{~cm}$, and a height of $21.5 \mathrm{~cm}$. It is made of perlite-reinforced insulated mortar $(5 \mathrm{~cm}$ thick), rock wool $(1.5 \mathrm{~cm}$ thick), and aluminum plate ( $1 \mathrm{~mm}$ thick). The drying cell was placed in the cylindrical space (approximately inner diameter $6 \mathrm{~cm}$ ) in the inner center of the reactor. The cylindrical drying cell has a diameter of $3.5 \mathrm{~cm}$, a height of $3 \mathrm{~cm}$, and a porous side surface area (nearly porous diameter $1-3 \mathrm{~mm}$ ). The drying cell made of galvanized steel plate ( $1 \mathrm{~mm}$ thick) is placed in the center of the PID system. In this system, temperatures can be controlled very precisely with the help of thermocouples. A certain amount of sample (1 gram) can be taken and the temperature can be easily distributed on all surfaces to the conductive and porous cell. 


\section{Thermal Decomposition Kinetics and Modeling}

In model equations: $M_{t}$ is the mass at time $t, M_{i}$ is the initial mass and $M_{f}$ is the final mass. $\alpha$ is the conversion ratio, $\beta$ is the temperature rise ratio, $k(T)$ is the temperature-dependent function and $f(\alpha)$ is the conversion-dependent function. $k(T)$ expresses the thermal decomposition rate constant, it is also a function that changes depending on the temperature. In experiments, the temperature increase in non-isothermal conditions changes the thermal decomposition rate constant over time. $f(\alpha)$ is a function depending on the conversion ratio and is defined as a special mathematical function that expresses the variation of the conversion ratio with time or temperature. The $g(x)$ function corresponds to the function found by integrating $d \alpha / f(\alpha)[41-44]$.

$$
\begin{aligned}
& \alpha=\frac{M_{t}-M_{f}}{M_{i}-M_{f}} \\
& k(T)=A \exp \left(-\frac{E}{R T}\right) \\
& \frac{d \alpha}{d t}=k(T) f(\alpha) \\
& f(\alpha)=(1-\alpha)^{n} \\
& \ln \left(\frac{g(\alpha)}{T^{2}}\right)=\ln \frac{A R}{E \beta}-\frac{E}{R T} \\
& \ln (\beta)=\ln \left(\frac{A E}{g(\alpha) R}\right)-5.3305-1.052\left(\frac{E}{R T}\right) \\
& \ln \left(\frac{\beta}{T^{2}}\right)=\ln \frac{A R}{g(\alpha) E}-\frac{E}{R T}
\end{aligned}
$$

The activation energy (E), Arrhenius constant ( $A)$, and $\mathrm{R}(8.314 \mathrm{~J} / \mathrm{mol} \cdot \mathrm{K})$ values are expressed from the model equations. In Eq. 3, it can be solved by writing Arrhenius Equation instead of $k(T)$. Coats Redfern (Eq. 5), Flynn Wall Ozawa (Eq. 6), and Kissinger (Eq. 7) models are shown in the above equations. Here, the activation energy values of the biocomposite have been calculated using Coats Redfern, Flynn Wall Ozawa, and Kissinger methods. According to Coats Redfern method, if the activation energy is plotted $1 / T$ versus $\ln (g(\alpha) /$ $T^{2}$ ), the slope gives $-E / R$. In the Flynn Wall Ozawa method, if $1 / T$ versus $\ln (\beta)$ is plotted on the graph, the slope is found

Table 1. Proximate analyses result of the experimental samples.

\begin{tabular}{cccc}
\hline Experiments & Moisture (\%) & Ash (\%) & Others (\%) \\
\hline Run No: 9 & 5.87 & 1.56 & 92.57 \\
Run No: 2 & 6.12 & 1.75 & 92.13 \\
Run No: 13 & 6.59 & 1.92 & 91.49 \\
\hline
\end{tabular}

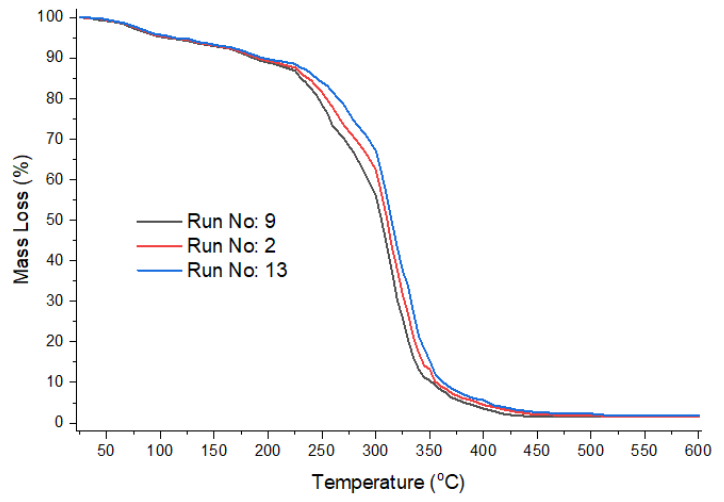

Figure 2. The effect of MPO content in the biocomposite for the thermal decomposition.

by the expression $-1.052 E / R$. In the Kissinger method, if $1 / T$ versus $\ln \left(\beta / T^{2}\right)$ is plotted, the slope is found as $-E / R$ [45-50].

\section{RESULTS AND DISCUSSIONS}

\section{Proximate Analysis of The Biocomposites}

Thermal degradation of biocomposites results is interpreted for specific experiments in Fig. 2 and Table 1. In thermal degradation experiments, physical decompositions (such as water, moisture) occurred in the first region, while chemical decompositions occurred in the second and third regions. It is possible to divide the chemical degradation of biocomposites into two in general. Weak structures that can chemically decompose at low temperatures degrade primarily in the composite, while groups with stronger thermal strength decompose slowly at higher temperatures [43-48].

\section{RSM Results for The Biocomposite}

According to the RSM experimental study plan, the rate of epoxy components (wt.\%) was kept constant in the production of the bio-epoxy composite. The mass percent values of epoxy resin and MPO have been entered into the program as the input data of RSM. RSM outputs are determined by the density of the obtained biocomposite, Shore D hardness, and thermal conductivity results. In Table 2, the experimental plan and response values arranged according to the RSM design are given.

In experimental studies, the results have been evaluated using analysis of variance (ANOVA) and RSM. When the obtained model equations are checked in ANOVA analysis, it is seen that the Quadratic Power model is suitable for this design. Also, $R^{2}$ values are found to be quite high and other error functions are also low.

According to the RSM results in Fig. 3, it is aimed to obtain maximum efficiency with the minimum economy 
Table 2. The experimental study and RSM of the bio-epoxy composites.

\begin{tabular}{cccccc}
\hline Run No & Epoxy Resin (wt.\%) & MPO (wt.\%) & Density $\left(\mathrm{kg} / \mathrm{m}^{3}\right)$ & Shore $D$ Hardness & $k(W / m \cdot K)$ \\
\hline 1 & 94.74 & 5.26 & 1164.27 & 74.39 & 0.097 \\
2 & 95.00 & 5.00 & 1161.96 & 74.46 & 0.096 \\
3 & 95.00 & 5.00 & 1161.97 & 74.47 & 0.096 \\
4 & 95.00 & 5.00 & 1161.98 & 74.48 & 0.096 \\
5 & 95.00 & 5.00 & 1161.96 & 74.46 & 0.096 \\
6 & 95.24 & 4.76 & 1159.89 & 74.55 & 0.095 \\
7 & 90.48 & 9.52 & 1201.47 & 73.02 & 0.111 \\
8 & 92.03 & 7.97 & 1187.92 & 73.52 & 0.106 \\
9 & 100.00 & 0.00 & 1118.30 & 76.07 & 0.079 \\
10 & 98.42 & 1.58 & 1132.07 & 75.57 & 0.084 \\
11 & 98.54 & 1.46 & 1131.09 & 75.60 & 0.084 \\
\hline 13 & 95.00 & 5.00 & 1161.97 & 74.47 & 0.096 \\
\hline & 91.46 & & 1192.84 & 73.34 & 0.108 \\
\hline
\end{tabular}

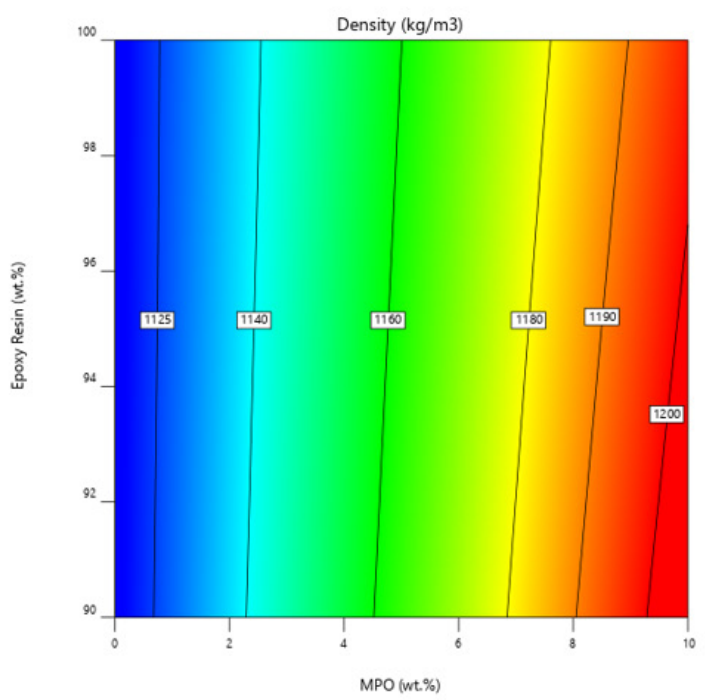

Figure 3. Effect of MPO (wt.\%) rate on the density of biocomposite.

under optimum conditions in experimental studies. This method will save both time and raw material spent. With this method, 13 experiments are performed in the experimental study plan of RSM and theoretically, at least 100 compatible results are found. In Fig. 3, it can be stated that the density of the biocomposite increases depending on the MPO rate. The density of the composite can vary according to the polymer matrix structure, pore distribution, additives, and fillers [51,52].

In Fig. 4, experimental data and RSM model results have been evaluated by statistical analysis. The distribution of the actual values and the predicted data within the $95 \%$

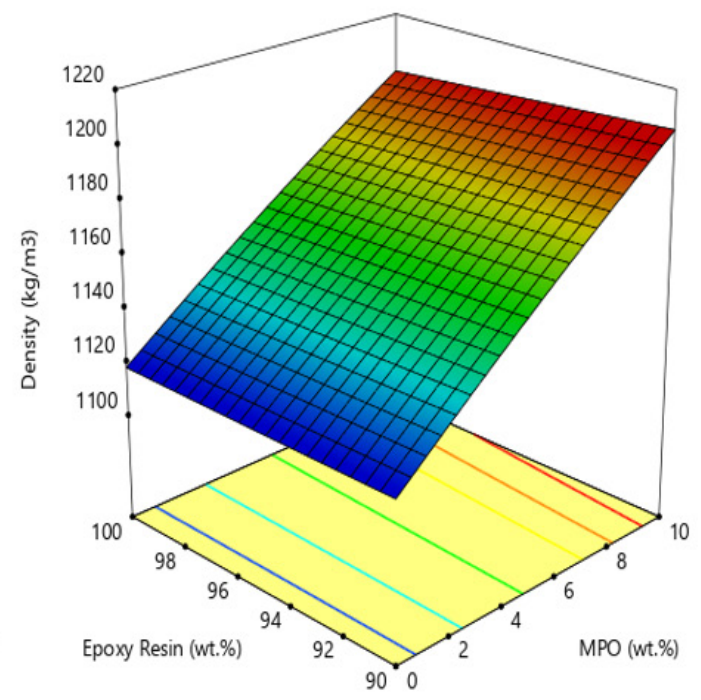

confidence interval is compared. In Eq. 8, the RSM polynomial function for density is expressed (A: MPO wt.\%, and B: Epoxy Resin wt.\%).

$$
\begin{aligned}
\rho= & +1160.36113+16.65252 \cdot A \\
& -0.853011 \cdot B-0.078989 \cdot A \cdot B \\
& -0.083227 \cdot A^{2}+0.004319 \cdot B^{2}
\end{aligned}
$$

It is seen in Fig. 5 that the Shore D hardness decreases as the rate of MPO by mass increases in the biocomposite. Fig. 6 shows the agreement between statistical analysis and experimental data and RSM model values. According to the power model in the RSM central composite method, the Shore D polynomial function is expressed in Eq. 9. 

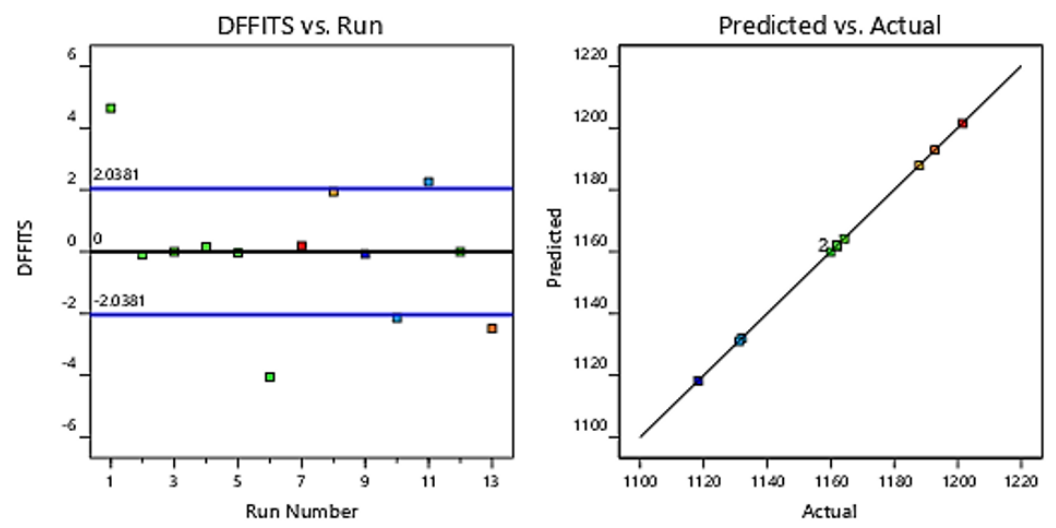

Figure 4. Comparison of experimental data and RSM model for the density of biocomposite.
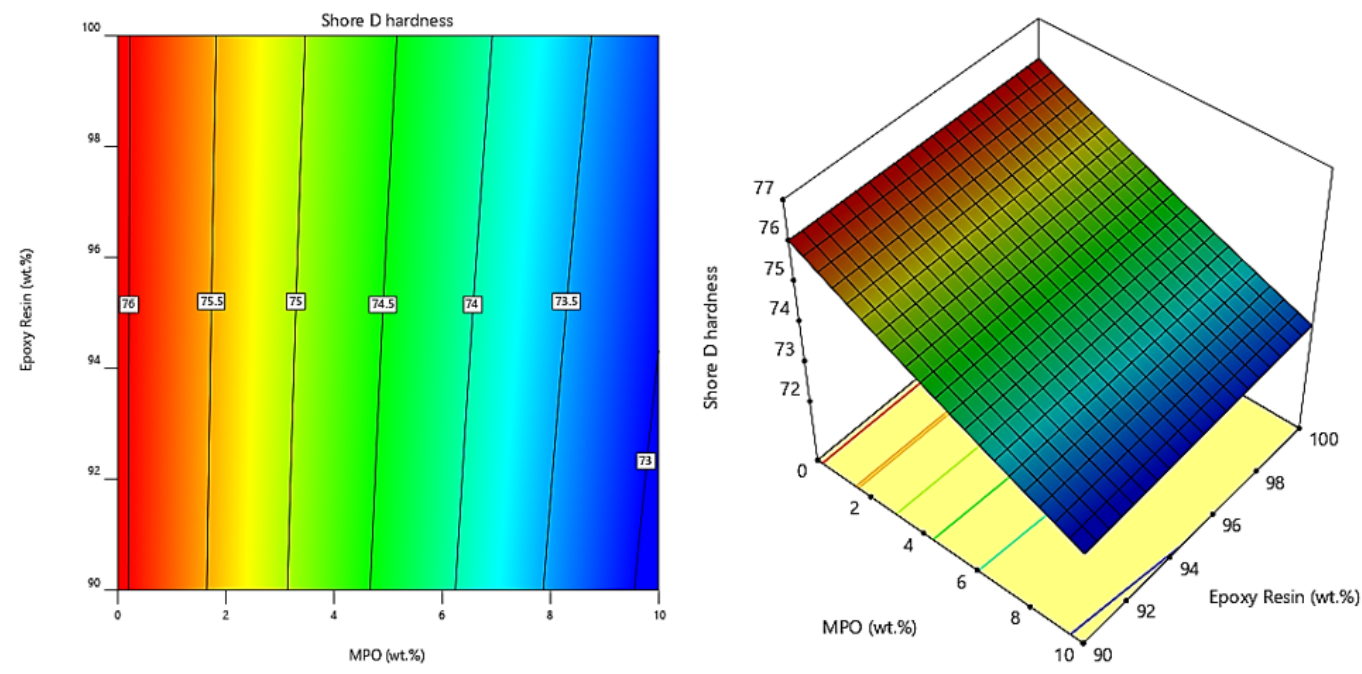

Figure 5. Effect of MPO (wt.\%) rate on Shore D hardness of the biocomposite.


Figure 6. Comparison of experimental data and RSM model for Shore D hardness.

$$
\begin{aligned}
\text { Shore } D & =+76.39007-0.620282 \cdot A \\
& -0.007175 \cdot B+0.003000 \cdot A \cdot B \\
& +0.003040 \cdot A^{2}+0.000040 \cdot B^{2}
\end{aligned}
$$

The effect of the MPO ratio on the thermal conductivity coefficient of the biocomposite is compared in Fig. 7 , and the compatibility of the experimental data with the theoretical model is evaluated in Fig. 8. The polynomial function expression of the thermal conductivity coefficient according to the RSM power model is expressed in Eq. 10.

$$
\begin{aligned}
& k=+0.098413+0.006392 \cdot A \\
& \quad-0.000399 \cdot B-0.000030 \cdot A \cdot B \\
&-0.000032 \cdot A^{2} \\
& 2.03223 \cdot 10^{-6} \cdot B^{2}
\end{aligned}
$$



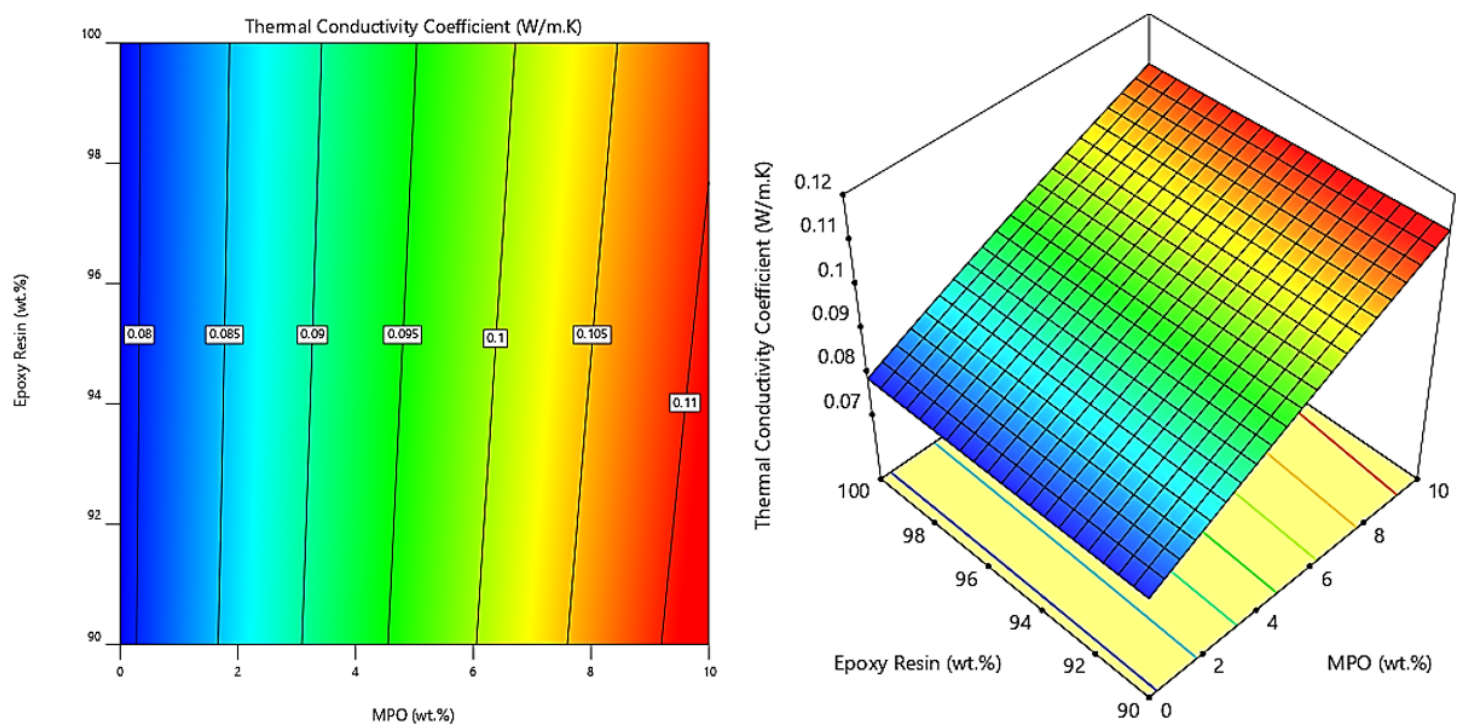

Figure 7. Effect of MPO (wt.\%) rate on the thermal conductivity of the biocomposite.
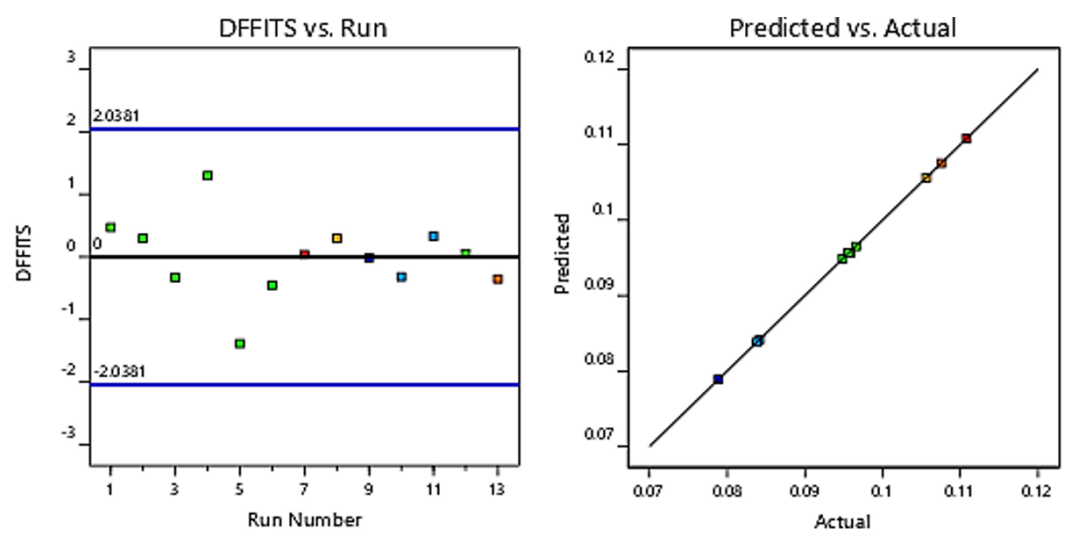

Figure 8. Comparison of experimental data and RSM model for the thermal conductivity.

Table 3. Statistical (ANOVA) evaluation of RSM results for the biocomposites.

\begin{tabular}{|c|c|c|c|c|c|c|c|}
\hline Parameters & Source & $P$-value & SST & Std. Dev. & C.V.\% & $R^{2}$ & Adj. $R^{2}$ \\
\hline$\rho\left(\mathrm{kg} / \mathrm{m}^{3}\right)$ & Quadratic & $<0.01$ & 7.78 & 0.0399 & 0.0134 & 0.9989 & 0.9976 \\
\hline Shore D & Quadratic & $<0.01$ & 1.13 & 0.0165 & 0.0120 & 0.9991 & 0.9985 \\
\hline$k(W / m \cdot K)$ & Quadratic & $<0.01$ & 0.64 & 0.0087 & 0.0901 & 0.9982 & 0.9973 \\
\hline
\end{tabular}

Statistical (ANOVA) evaluation for density, Shore D hardness, and coefficient of thermal conductivity is given in Table 3. High $R^{2}$ and adjusted $R^{2}$ values, good RSM model significance values (P-value $<0.01$ ), low error function (SST), and low standard deviation indicate that the theoretical model is successful according to the experimental results [53-57].

\section{FTIR Spectrophotometer}

FTIR spectrum of extracted oil samples attained in the wavenumber region between 4000 and $600 \mathrm{~cm}^{-1}$. The result from FTIR is tabulated in Table 4 . At the vibra- tion at $3005 \mathrm{~cm}^{-1}$, a stretch of $=\mathrm{C}-\mathrm{H}$, corresponding to an alkene, is observed. Symmetrical and asymmetrical stretching of $\mathrm{C}-\mathrm{H}$ is observed in vibration at 2922 and $2852 \mathrm{~cm}^{-1}$. The intense band observed at $1743 \mathrm{~cm}^{-1}$ is the result of $\mathrm{C}=\mathrm{O}$ vibrations indicating the presence of saturated aliphatic esters. This group is also known as triglyceride, the predominant component in fats and oils [58]. The peak at $1510 \mathrm{~cm}^{-1}$ indicates stretching of the $\mathrm{C}=\mathrm{C}$ of the alkene group. The peak at $1460 \mathrm{~cm}^{-1}$ is observed due to $\mathrm{C}-\mathrm{C}$ stretching in the aromatics group [59]. The peak at $3478 \mathrm{~cm}^{-1}$, which occurs with the modification of palm oil, belongs to the hydroxyl group. It shows that the structure which is expected to disappear after the 
Table 4. Results from FTIR analysis of the components.

\begin{tabular}{|c|c|c|c|}
\hline & Palm oil peak $\left(\mathrm{cm}^{-1}\right)$ & Epoxy Palm oil peak $\left(\mathrm{cm}^{-1}\right)$ & $M P O\left(\mathrm{~cm}^{-1}\right)$ \\
\hline$-\mathrm{OH}$ & $---\cdot$ & 3478 & $3538-3500$ \\
\hline$-\mathrm{SO}_{2}-\mathrm{N}-\mathrm{H}$ & $---\cdot$ & $-\cdots-$ & $3357-3269$ \\
\hline Stretching of $=\mathrm{C}-\mathrm{H}$ & 3005 & $-\cdots-$ & --- \\
\hline $\begin{array}{c}\text { Symmetric and Asymmetric } \\
\text { stretching of } C-H\end{array}$ & $2922-2852$ & $2929-2875$ & $2945-2858$ \\
\hline Triglyceride (TGA) & 1743 & 1628 & 1721 \\
\hline Stretching of $C=C$ & 1510 & $-\cdots--$ & \\
\hline Stretching of C-C & 1460 & 1455 & \\
\hline Asymmetric stretching $-\mathrm{SO}_{2}$ & --- & $-\cdots$ & $1367-1228$ \\
\hline Oxirane group & $-\cdots-$ & 833 & $-\cdots$ \\
\hline
\end{tabular}

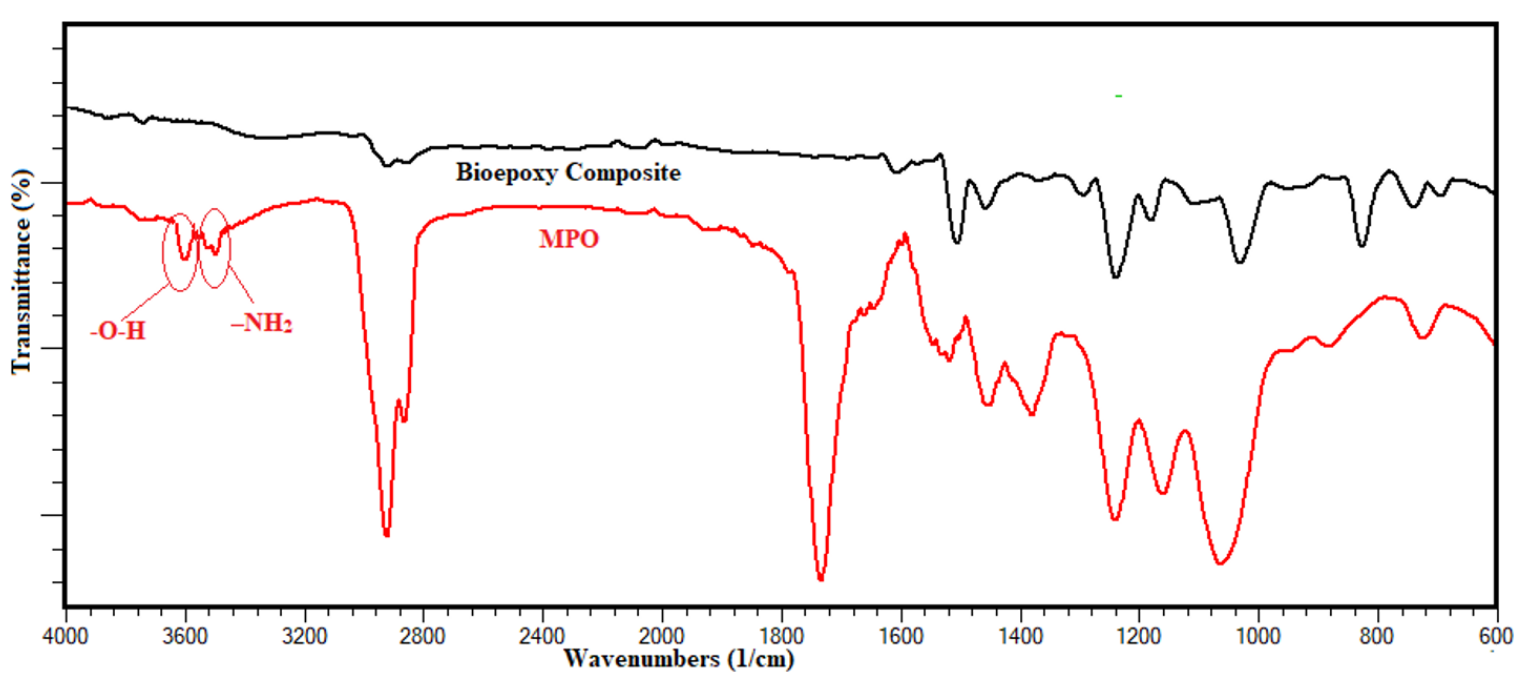

Figure 9. FTIR spectrum of the biocomposite and MPO.

modification of $=\mathrm{C}-\mathrm{H}$ and $\mathrm{C}=\mathrm{C}$ stresses corresponding to an alkene in vibration at $3005 \mathrm{~cm}^{-1}$ and $1510 \mathrm{~cm}^{-1}$ is formed. However, the peak formation of the oxirane group at $833 \mathrm{~cm}^{-1}$ supports the expected structure [60]. The peaks at 3357 and $3269 \mathrm{~cm}^{-1}$ observed in MPO spectrum belong to the $-\mathrm{SO}_{2}-\mathrm{N}-\mathrm{H}$ group [61-63]. The observation of 1367 and $1228 \mathrm{~cm}^{-1}$ asymmetric stretching peaks of $-\mathrm{SO}_{2}$ confirms the binding [64]. Epoxide ring-opening is generally observed with an increasing peak of hydroxyl peak. It is known that the shift of the hydroxyl characteristic peak from high to low wave number represents increased hydrogen bonding in the network. However, the disappearance of the oxirane peaks at $833 \mathrm{~cm}^{-1}$ and the increase in the hydroxyl peak intensity confirm this information.

The FTIR spectrum in Fig. 9 shows the chemical bonds found in MPO and biocomposite. The disappearance of both $-\mathrm{O}-\mathrm{H}$ groups and $-\mathrm{NH}_{2}$ groups in MPO in the biocomposite indicates that these groups are lost by entering the chemical reaction.

\section{CONCLUSION}

According to the results obtained, although the increase in the MPO ratio by mass increased the density, thermal conductivity, and thermal stability of the bio-epoxy composite, it decreased the Shore D hardness.

As the MPO rate (wt.\%) in the produced biocomposite goes up, the thermal stability of the composite also rises. Calculated activation energies of the biocomposite according to the Flynn Wall Ozawa method are found to be $139.65 \mathrm{~kJ} / \mathrm{mol}$ (Run No: 9), $143.56 \mathrm{~kJ} / \mathrm{mol}$ (Run No: 2), and $145.28 \mathrm{~kJ} / \mathrm{mol}$ (Run No: 13). According to the Coats Redfern method, the best model is determined by the function $\left(f=(1-\alpha)^{1.273}\right)$. Coats Redfern, Flynn Wall Ozawa, and Kissinger model results, the deviation in the calculated activation energy values of the biocomposites are found below $7 \%$. Experimental studies are carried out under non-isothermal conditions, and kinetic parameters are calculated with the best model approach. The model results are found in the 
statistical analysis with minimum $\mathrm{R}^{2}$ error functions and maximum efficiency values.

\section{CONFLICT OF INTEREST}

The authors declare that they have no known competing financial interests or personal relationships that could have appeared to influence the work reported in this paper.

\section{AUTHOR CONTRIBUTION}

All the work in this study were performed equally by the authors.

\section{References}

1. Zamri MH, Akil HM, MohdIshak ZA. Pultruded Kenaf Fibre Reinforced Composites: Effect of Different Kenaf Fibre Yarn Tex. Procedia Chem. 19 (2016) 577-585.

2. Ilyas RA, Sapuan SM. The Preparation Methods and Processing of Natural Fibre Biopolymer Composites. Curr. Org. Synth. 16 (2020) 1068-1070.

3. Ilyas RA, Sapuan SM. Biopolymers and Biocomposites: Chemistry and Technology. Curr. Anal. Chem. 16 (2020) 500-503.

4. Abral H, Atmajaya A, Mahardika M, Hafizulhaq F, Handayani DK, Sapuan SM, Ilyas RA. Effect of ultrasonication duration of polyvinyl alcohol (PVA) gel on characterizations of PVA film. J. Mater. Res. Technol. 9 (2020) 2477-2486.

5. Faruk O, Bledzki AK, Fink HP, Sain M. Biocomposites reinforced with natural fibers: 2000-2010. Prog. Polym. Sci. 37 (2012) $1552-$ 1596.

6. Ilyas RA, Sapuan SM, Atikah, MSN, Asyraf MRM, Rafiqah SA, Aisyah HA, Nurazzi NM, Norrrahim MNF. Effect of hydrolysis time on the morphological, physical, chemical and thermal behavior of sugar palm nanocrystalline cellulose (Arenga pinnata (Wurmb.) Merr). Text. Res. J. 91(2021) 152-167.

7. Ilyas RA, Sapuan SM, Ibrahim R, Abral H, Ishak MR, Zainudin ES, Atikah MSN, Mohd Nurazzi N, Atiqah A, Ansari MNM, Syafri E, Asrofi M, Sari NH, Cumaidink R. Effect of sugar palm nanofibrillated cellulose concentrations on morphological, mechanical and physical properties of biodegradable films based on agro-waste sugar palm (Arenga pinnata (Wurmb.) Merr) starch. J. Mater. Res. Technol. 8 (2019) 4819-4830.

8. Ilyas RA, Sapuan SM, Ibrahim R, Abral H, Ishak MR, Zainudin ES, Asrofi M, Atikah MSN, Huzaifah MMR, Radzi AM, Azammi AMN Shaharuzaman MA, Nurazzi NM, Syafri E, Sari NH, Norrrahim MRF, Jumaidinp R. Sugar palm (Arenga pinnata (Wurmb.) Merr) cellulosic fibre hierarchy: A comprehensive approach from macro to nanoscale. J. Mater. Res. Technol. 8 (2019) 2753-2766.

9. Aisyah HA, Paridah MT, Sapuan SM, Khalina A, Berkalp OB, Lee SH, Lee CH, Nurazzi NM, Ramli N, Wahab MS, Ilyas RA. Thermal Properties of Woven Kenaf/Carbon Fibre-Reinforced Epoxy Hybrid Composite Panels. Int. J. Polym. Sci. (2019) 1-8.

10. Jumaidin R, Saidi ZAS, Ilyas RA, Ahmad MN, Wahid MK, Yaakob MY, Maidin NA, Rahman MHA, Osman MH. Characteristics of Cogon Grass Fibre Reinforced Thermoplastic Cassava Starch Biocomposite: Water Absorption and Physical Properties. J. Adv. Res. Fluid Mech. Therm. Sci. 62 (2019) 43-52.
11. Alsubari S, Zuhri MYM, Sapuan SM, Ishak M.R, Ilyas R.A, Asyraf M.R.M. Potential of Natural Fiber Reinforced Polymer Composites in Sandwich Structures: A Review on Its Mechanical Properties. Polymers 13 (2021) 423.

12. Omran AAB, Mohammed AABA, Sapuan SM, Ilyas RA, Asyraf MRM, Koloor SSR, Petru M. Micro- and Nanocellulose in Polymer Composite Materials: A Review. Polymers. 13 (2021) 231.

13. Nurazzi MN, Asyraf MRM, Khalina A, Abdullah N, Sabaruddin FA, Kamarudin SH, Ahmad S, Mahat AM, Lee C.L, Aisyah H.A, Norrahim MNF, İlyas RA, Harussani MM, Ishak B, Sapuanca SM. Fabrication, Functionalization, and Application of Carbon Nanotube-Reinforced Polymer Composite: An Overview. Polymers. 13 (2021) 1047.

14. Aisyah HA, Paridah MT, Sapuan SM, Ilyas RA, Khalina A, Nurazzi NM, Lee SH, Lee CH. A Comprehensive Review on Advanced Sustainable Woven Natural Fibre Polymer Composites. Polymers. 13 (2021) 471.

15. Jumaidin R, Khiruddin MAA, Saidi ASZ, Salit MS, Ilyas RA. Effect of cogon grass fibre on the thermal, mechanical and biodegradation properties of thermoplastic cassava starch biocomposite. Int. J. Biol. Macromol. 146 (2020) 746-755.

16. Sanjay MR, Arpitha GR, Naik LL, Gopalakrishna K, Yogesha B. Applications of Natural Fibers and Its Composites: An Overview. Nat. Resour. 7 (2016)108-114.

17. Asyraf MRM, Ishak MR, Sapuan SM, Yidris N, Ilyas RA. Woods and composites cantilever beam: A comprehensive review of experimental and numerical creep methodologies. J. Mater. Res. Technol. 9 (2020) 6759-6776.

18. Ayu RS, Khalina A, Harmaen A.S, Zaman K, Isma T, Liu Q, Ilyas RA, Lee CH. Characterization Study of Empty Fruit Bunch (EFB) Fibers Reinforcement in Poly (Butylene) Succinate (PBS)/Starch/ Glycerol Composite Sheet. Polymers. 12 (2020) 1571.

19. Holbery J, Houston D. Natural-fiber-reinforced polymer composites in automotive applications. JOM. 58 (2006) 80-86.

20. Kim YK, Chalivendra V. Natural fibre composites (NFCs) for construction and automotive industries. In Handbook of Natural Fibres; Elsevier: Amsterdam, The Netherlands, 469-498, 2020

21. Fragassa C. Marine applications of natural fibre-reinforced composites: A manufacturing case study. In Advances in Applications of Industrial Biomaterials; Springer: Berlin/ Heidelberg, Germany, 21-47, 2017.

22. Jaafar ACN, Zainol I, Ishak NS, Ilyas RA, Sapuan SM. Effects of the Liquid Natural Rubber (LNR) on Mechanical Properties and Microstructure of Epoxy/Silica/Kenaf Hybrid Composite for Potential Automotive Applications. J. Mater. Res. Technol. 12 (2021) 1026-1038.

23. Rezaifard AH, Hodd KA, Tod DA, Barton JM. Toughening epoxy resins with poly (methyl methacrylate)-grafter-natural rubber and its use in adhesive formulations. Int. J. Adhes. Adhes. 14 (1994) $153-159$.

24. Technotes BE. Composite Recycling, and Disposal An Environmental R\&D Issue. Boeing Environ. Technotes. 8 (2003) $1-4$.

25. Bandyopadhyay S. Source composite curve for waste reduction. Chem. Eng. J. 125 (2006) 99-110.

26. Sanjay MR, Madhu P, Jawaid M, Senthamaraikannan P, Senthil S, Pradeep S. Characterization and properties of natural fiber polymer composites: A comprehensive review. J. Clean. Prod. 172 (2018) 566-581.

27. Vinod A, Sanjay MR, Suchart S, Jyotishkumar P. Renewable and sustainable biobased materials: An assessment on biofibers, biofilms, biopolymers, and biocomposites. J. Clean. Prod. 258 
(2020) 120978

28. Ramnath VB, Kokan JS, Raja NR, Sathyanarayanan R, Elanchezhian C, Prasad RA, Manickavasagam V.M. Evaluation of mechanical properties of abaca-jute-glass fibre reinforced epoxy composite. Mater. Des. 51 (2013) 357-366.

29. Szolnoki B, Bocz K, Sóti PL, Bodzay B, Zimonyi E, Toldy A, Morlin B, Bujnowicz K, Wladyka-Przybylak M, Marosi G. Development of natural fibre reinforced flame retarded epoxy resin composites. Polym. Degrad. Stab. 119 (2015) 68-76.

30. Pickering KL, Le TM. High performance aligned short natural fibre-Epoxy composites. Compos. Part B Eng. 85 (2016) 123-129.

31. Mittal V, Saini R, Sinha S. Natural fiber-mediated epoxy composites-A review. Compos. Part B 99 (2016) 425-435.

32. Abu Bakar MA, Ahmad S, Kuntjoro W. Effect of epoxidized natural rubber on mechanical properties of epoxy reinforced kenaf fibre composites. Pertanika J. Sci. Technol. 20 (2012) 129-137.

33. Hassan F, Zulkifli R, Ghazali MJ, Azhari CH. Kenaf Fiber Composite in Automotive Industry: An Overview. Int. J. Adv. Sci. Eng. Inf. Technol. 7 (2017) 315.

34. Nurazzi NM, Khalina A, Sapuan SM, Ilyas, R.A. Mechanical properties of sugar palm yarn/woven glass fiber reinforced unsaturated polyester composites: Effect of fiber loadings and alkaline treatment. Polimery. 64 (2019) 12-22.

35. Rihayat T, Suryani S, Fauzi T, Agusnar H, Wirjosentono B, Syafruddin, Helmi, Zulkifli, Alam PN, Sami M. . Mechanical properties evaluation of single and hybrid composites epoxy reinforced bamboo, PALF and coir fiber. IOP Conf Ser Mater Sci Eng. 334 (2018) 012081. doi:10.1088/1757-899X/334/1/012081

36. Wang F, Shao Z. Study on the variation law of bamboo fibers' tensile properties and the organization structure on the radial direction of bamboo stem. Ind Cros Products. 152 (2020) 112521.

37. Mahmoud MA. Oil spill cleanup by raw flax fiber: modification effect, sorption isotherm, kinetics, and thermodynamics. Arabian J Chem. 13 (2020) 5553- 5563

38. Kang JT, Kim SH. Improvement in the mechanical properties of polylactide and bamboo fiber biocomposites by fiber surface modification. Macromol Res. 19 (2011)789-796.

39. Lee SH, Wang S. Biodegradable polymers/bamboo fiber biocomposite with bio-based coupling agent. Compos Appl Sci Manuf. 37 (2006) 80-91.

40. Fan M. Chemical compositions of natural fibres. In: S. R. Reid, G. Zhou, editors. Advanced high strength natural fibre composites in construction. London: Woodhead Publishing, 35-41, 2016.

41. Fernandes, F. C., Kirwan, K., Lehane, D., \& Coles, S. R. (2017) Epoxy resin blends and composites from waste vegetable oil European Polymer Journal, 89, 449-460. https://doi.org/10.1016/j. eurpolymj.2017.02.005

42. Vural Kök, B., Aydoğmuş, E., Yilmaz, M., \& Akpolat, M. (2021) Investigation on the properties of new palm-oil-based polyurethane modified bitumen. Construction and Building Materials, 289 https://doi.org/10.1016/j.conbuildmat.2021.123152

43. Aydoğmuş, E., Arslanoğlu, H., \& Dağ, M. (2021). Production of waste polyethylene terephthalate reinforced biocomposite with RSM design and evaluation of thermophysical properties by ANN. Journal of Building Engineering, 44, 103337. https://doi org/10.1016/j.jobe.2021.103337

44. Mustapha, R., Rahmat, A. R., Abdul Majid, R., \& Mustapha, S. N. H (2019). Vegetable oil-based epoxy resins and their composites with bio-based hardener: a short review. In Polymer-Plastics Technology and Materials (Vol. 58, Issue 12, pp. 1311-1326). Taylor and Francis Inc. https://doi.org/10.1080/25740881.2018.1563119

45. Xu Y, Yang Y, Shen R, Parker T, Zhang Y, Wang Z, Wang Q. Therma behavior and kinetics study of carbon/epoxy resin composites. Polymer Composites, 40 (2019) 4530-4546. https://doi.org/10.1002/ pc. 25309

46. Tikhani F, Moghari S, Jouyandeh M, Laoutid F, Vahabi H, Saeb MR, Dubois P. Curing kinetics and thermal stability of epoxy composites containing newly obtained nano-scale aluminum hypophosphite (AlPO2). Polymers. 12 (2020), 1-22. https://doi. org/10.3390/polym12030644

47. Tranchard P, Samyn F, Duquesne S, Estèbe B, Bourbigot S. Modelling behaviour of a carbon epoxy composite exposed to fire: Part I-Characterisation of thermophysical properties. Materials, 10 (2017) 494. https://doi.org/10.3390/ma10050494

48. Tranchard P, Duquesne S, Samyn F, Estèbe B, Bourbigot S. Kinetic analysis of the thermal decomposition of a carbon fibre-reinforced epoxy resin laminate. Journal of Analytical and Applied Pyrolysis, 126 (2017) 14-21. https://doi.org/10.1016/j.jaap.2017.07.002

49. Wang R, Xie C, Zeng L, Xu H. Thermal decomposition behavior and kinetics of nanocomposites at low-modified $\mathrm{ZnO}$ content. RSC Advances. 9 (2019), 790-800. https://doi.org/10.1039/c8ra09206k

50. Xiong X, Zhou L, Ren R, Liu S, Chen P. The thermal decomposition behavior and kinetics of epoxy resins cured with a novel phthalidecontaining aromatic diamine. Polymer Testing. 68 (2018) 46-52. https://doi.org/10.1016/j.polymertesting.2018.02.012

51. Hassan MZ, Sapuan SM, Roslan SA, Aziz SA, Sarip S. Optimization of tensile behavior of banana pseudo-stem (Musa acuminate) fiber reinforced epoxy composites using response surface methodology. Journal of Materials Research and Technology, 8 (2019), 3517-3528. https://doi.org/10.1016/j.jmrt.2019.06.026

52. Sinha AK, Bhattacharya S, Narang HK. Experimental determination and modelling of the mechanical properties of hybrid abaca-reinforced polymer composite using RSM. Polymers and Polymer Composites, 27 (2019) 597-608. https://doi. org/10.1177/0967391119855843

53. Oladele IO, Akinola OS, Agbabiaka OG, Omotoyinbo JA. Mathematical Model for the Prediction of Impact Energy of Organic Material Based Hydroxyapatite (HAp) Reinforced Epoxy Composites. Fibers and Polymers. 19 (2018), 452-459. https://doi. org/10.1007/s12221-018-7844-5

54. Antil P. Modelling and Multi-Objective Optimization during ECDM of Silicon Carbide Reinforced Epoxy Composites. Silicon, 12 (2020) 275-288. https://doi.org/10.1007/s12633-019-00122-8

55. Sinha AK, Narang HK, Bhattacharya S. Experimental Determination, Modelling and Prediction of Sliding Wear of Hybrid Polymer Composites Using RSM and Fuzzy Logic. Arabian Journal for Science and Engineering, 46(3), 2071-2082. https://doi. org/10.1007/s13369-020-04997-3

56. Sarafrazi, M., Hamadanian, M., \& Ghasemi, A. R. (2019). Optimize epoxy matrix with RSM/CCD method and influence of multi-wall carbon nanotube on mechanical properties of epoxy/polyurethane. Mechanics of Materials, 138 (2021) 103154. https://doi.org/10.1016/j. mechmat.2019.103154

57. Dadrasi A, Farzi GA, Shariati M, Fooladpanjeh S, Parvaneh V. Experimental study and optimization of fracture properties of epoxy-based nano-composites: Effect of using nano-silica by GEP, RSM, DTM and PSO. Engineering Fracture Mechanics. 232 (2020), 107047. https://doi.org/10.1016/j.engfracmech.2020.107047

58. Wahab, AAA, Chang SH, Som, AM. Characterisation of waste cooking oil as a potential green solvent for liquid-liquid extraction. International Conference on Advances in Civil and Environmental Engineering, s. 20-28, 2015.

59. Lim SF, Hamdan A, Chua SND, Lim BH. Comparison and optimization of conventional and ultrasound-assisted solvent 
extraction for synthetization of lemongrass (Cymbopogon)infused cooking oil. Food Sci Nutr. 9 (2021) 2722-2732. DOI: 10.1002/fsn3.2234

60. El-Aouni N, Hsissou R, El Azzaoui J, El Bouchti M, Elbachiri A, Elharfi A, Rafik M. One-pot Synthesis of Trifunctional Epoxy Resin and its Nanocomposite: Investigation of Thermal and Rheological Properties, Biointerface Res. Appl. Chem. 11 (2021) 12403-12413. https://doi.org/10.33263/BRIAC114.1240312413

61. Baxter JN, Cymerman-Craig J, Willis JB. The infrared spectra of some sulphonamides. J. Chem. Soc. (1955) 669-679.

62. Goldstein M, Russell MA, Willis HA. The infrared spectra of N-substituted sulphonamides. Spectrochim. Acta A. 25 (1969) 1275-1285.
63. Reiss A, Cioateră N, Dobritescu A, Rotaru M, Carabet AC, Parisi F, Gănescu A, Dăbuleanu I, Spînu CI, Rotaru P. Bioactive $\mathrm{Co}(\mathrm{II}), \mathrm{Ni}(\mathrm{II})$, and $\mathrm{Cu}(\mathrm{II})$ Complexes Containing a Tridentate Sulfathiazole-Based (ONN) Schiff Base. Molecules 26 (2021) 3062. https://doi.org/10.3390/molecules26103062

64. Mubarik A, Rasool N, Hashmi MA, Mansha A, Zubair M, Shaik MR, Sharaf MAF, Awwad EM, Abdelgawad A. Computational Study of Structural, Molecular Orbitals, Optical and Thermodynamic Parameters of Thiophene Sulfonamide Derivatives. Crystals. 11 (2021) 211. https://doi.org/10.3390/cryst11020211 